series of spines on the tail, the two central ones being much smaller, while the outer ones are of extraordinary size and appearance. The inferior surface of the tail is occupied by smooth elongate scales in about 17 transverse rows, a very large, flat, unguicular plate at the commencement of each alternate row accompanying each of the large lateral hooks just described, but belonging to the lower surface of the tail.

As regards the teeth, this species exhibits the arrangement characteristic of the Lizards of this group. There are two very distinct front teeth in each jaw, then a cutting-edge, followed by a series of lateral teeth.

The general colour of the body is olive-grey, with brownish tints, and minute darker spots scattered over the back ; hind limbs reddish on their outer surfaces; tail deep red; chin variegated with dark markings.

The measurements are as follows :-

\begin{tabular}{|c|c|c|}
\hline \multicolumn{2}{|c|}{ Length from tip of snout to extremity of tail $\ldots$. } & $\begin{array}{l}\text { millims. } \\
190\end{array}$ \\
\hline & of tail $\ldots \ldots \ldots \ldots \ldots \ldots \ldots \ldots$ & 61 \\
\hline & of fore limb....... & 52 \\
\hline & of fourth front toe & 14 \\
\hline & of third front toe.. & 12 \\
\hline , & of hind limb $\ldots$ & 67 \\
\hline ", & of fourth hind to & 17 \\
\hline & of third hind toe.. & 14 \\
\hline
\end{tabular}

6. On the Breeding of the Flamingo in Southern Spain. By Thomas Lytrleton, LoRd Lilford, F.Z.S.

[Received June 1, 1880.]

Having during the summer and autumn of last year (1879) reeeived the two nests now on the table and some four dozen eggs of the Flamingo (Phoenicopterus antiquorum) from Southern Spain, I think that some remarks of my own, and a few extracts from letters on the subject, may be of some interest to the Society.

The notes of Mr. Howard Saunders on the nesting of the Flamingo (in the 'Ibis' for 1871, p. 394) are probably well known to all present who take an interest in European ornithology. Mr. Saunders also exhibited some eggs of this species from Andalucia, at a meeting of this Society on June 24, 1869; but, so far as I am aware, these are the first nests of this bird which have reached this country. Exactly the same story as that recorded by Saunders about the nests, eggs, and manner of sitting of the Flamingo was related to me, and repeated at various times, by his informant, Manuel Llanos, of Coria del Rio, a village situated on the right bank of the Guadalquivir, some seven or eight miles below Seville. This individual is the possessor of a house in Coria, with a few acres of vineyard at a 
short distance from that village, but subsists principally by the sale of wild fowl killed by himself and his sons in the Marisma-that is, the great alluvial plains of the Guadalquivir. These plains, roughly speaking, may be said to extend on the left bank of the main river almost from Seville to San Lucar de Barrameda, and on the right bank from La Puebla to the northern edge of the Coto de Doñana, and constitute a wild district of sand hills overgrown in some places with pines and cork-trees, and almost everywhere clothed with a dense growth of cistus, rosemary, lentiscus, brambles, myrtle, and other shrubs. This district belongs to the ducal family of Medina Sidonia, and is rented and preserved after a fashion by an association of gentlemen for shooting-purposes. I am well aware that in using the word marisma as applying to the whole of the open plains below Seville I am not strictly correct, for the natives apply the term principally, if not exclusively, to the uncultivated parts of the said plains ; and a vast portion of them is cultivated, and produces splendid crops of wheat, barley, beans, and other cereals. It is, however, with the southwestern portion of these great mud-flats (for they are really little more) that we have to deal in treating of the objects on the table; but before detailing any particulars concerning them, I may perhaps be allowed to relate a few facts touching upon my own personal acquaintance with these localities and the Flamingos.

The first time I ever met with this bird in a state of freedom was in August 1856, when ascending the Guadalquivir by steamer from San Lucar to Seville. The river was very low, and the weather very hot. An English stoker forward in the ship cried out, "Look at these here Swans"! and there, not fifty yards off, on our port bow, were eight Flamingos, apparently swimming, possibly wading, and certainly looking much like Swans to the eye of the unitiated; however, they rose from the water, and, spreading their wings, almost took away the breath of the astonished Briton. I tried to elicit some particulars concerning the nesting of these birds from the captain and the steward of the steamer; but my conversational acquaintance with Spanish was very limited, and the heat was too great for conversation, so that my inquiries were only met by another, the usual "Quien sabe ?" On making further inquiries in Seville, I could only learn that every one was aware of the existence of Flamingos in the Marisma, but no one seemed to know any thing of their breeding or ever having bred there. I was again at Seville in 1864, and though I was on this occasion informed that great numbers of Flamingos did occasionally breed in the Marisma, I could find no one who professed to have ever seen their nests, eggs, or young. It was not till 1869, when, in the company of my friend Colonel Howard Irby and the Manuel aforesaid, I made some bird-collecting expeditions in the neighbourhood of Seville, that I heard from the latter the particulars recorded by Mr. Howard Saunders in the 'Ibis.'

As Mr. Saunders there mentions, I remained at Seville till well on into the month of June 1869, principally in the hope that the Flamingos might remain and lay in the Marisma; but in this hope $\mathrm{I}$ was disappointed ; and I quite agree in the opinion of $\mathrm{Mr}$. Saunders, 
if I quite rightly understand it, that no Flamingos had nested within thirty miles of Seville for several years previous to 1870 .

In the year 1872 I again visited Seville, remaining there from the middle of February till the 1st of May, on which day we started by steamer for San Lucar de Barrameda for a fortnight's exploration of the Coto de Doñana. As soon as we left the cultivated parts of the great plain, we observed Flamingos in thousands standing in long lines in the lucios ${ }^{1}$ of the Isla Mayor ${ }^{2}$, as well as on the left bank of the main river as we approached San Lucar. On arrival at this town, my first inquiry was if the Flamingos were nesting; and the general answer I met with was, " No, there is not water enough, and they are leaving the country in hundreds for the south every night you should have been here at this time the year before last (1870), when ${ }^{3}$ the Isla Mayor was fairly covered with their eggs, and boatloads of them were brought into the town and sold for a few pence per dozen, and the boys were writing on all the doors and walls with the egg-shells. In vain I inquired about the nests; no one had either seen or heard of one ; and many of my informants, who had gathered baskets full of the eggs, solemnly declared that the Flamingos never did make nests, and left their eggs to be hatched by the heat of the sun. We remained at the shooting-lodges of the Coto de Doñana till May 16th ; and almost every night large numbers of Flamingos passed over in a south-westerly direction at no very great height from the ground, with a hoarse clamour something like the music of a flock of Grey-Lag Geese. On ascending the river about the 17th of May, on our return to Seville, we saw, comparatively speakiing, very few Flamingos, not more, I should say, than two hundred at the outside; but the mirage was so strong and so deceitful, that it is possible that many escaped our notice.

Two eggs were sent to me by one of the keepers of the Coto in the autumn of 1872 ; but he simply said that he had picked them up in the Marisma, and that they were offensively rotten, possibly eggs of 1870 . I was in Seville again with my yacht in February and March 1879; but though I heard that the Flamingos were in the Isla Mayor in great numbers, we did not see many on our Bustardshooting expeditions in the Isla Menor.

I left earnest entreaties for early information on the subject of their remaining to lay, with the following meagre results.

1 "Lucio." The only translation of this substantive which I can find in the best Spanish dietionary is Common Pike, Esox lucius, L. ; but it is used in the Marisma of the Guadalquivir as a name for the great sheets of water caused by the autumnal rains, some of which sheets are seldom entirely dried up, even in the fiereest summer heats. The word is in all probability derived from the verb "Lucir," to shine or glitter; e.g., "Todo no es oro que reluce" (" all is not gold that glitters").

2 Isla Mayor and Menor. Two large islands formed by branches of the Guadalquivir, about halfway, roughly speaking, from Seville to San Lucar de Barrameda by river.

${ }^{3} \mathrm{Mr}$. Howard Saunders maintains that I must be mistaken as to the date here mentioned, and that the laying of the Flamingos as related to me must have taken place in 1871 , and not, as I was informed, in 1870 . This is not a very material point, and I only tell the story as told to me. 
From Alberto Ruiz, a young medical man of Seville, who has travelled with me as preserver of natural-history objects in Spain and various parts of the Mediterranean, I received letters from which the following extracts are translated :

“I "June 19, 1879.

have the pleasure able to obtain a few eggs of Flamingo, which I shall On another occasion I will to you with some others from Manuel. \&c."

"The Flamingos have not bred "July 11, 1879. laid a few eggs ; for the number of persons who hear, and have only great that they do not allow them to build their nests. found the egros which he has brought to me in spot which is called La Redondilla chica, in the Isla Mayor, in a water-"lucio," in the close neighbourh scattered about, not in the water. I of which he found the eggs found in the gathered his the 21st, 22nd, and 23rd of the same month.",

Enclosed is a bill "July 17, 1879. ( $F$. feldegii), and a box lading of the cage which contains the Falcon has prepared, and 47 with a skin of Black Vulture that Manuel aforesaid brought to me. In my pro, 20 of which the old hunter dates of the gathering of the egros, previous letter I gave you the gard to the month, which was April, instead of May."

"The evening before last I recived "July $24,1879$. them some new particulars, which I am going to relate egs, and with may be of any interest. There is a going to relate in case they Real in the Isla Mayor, which is a lagoon to the south of the Lucio it a new cut, or channel. Well, in thosed Lucio de la Sal, and close to have laid in the greatest abundance, and inces is where the Flamingos infinity of nests, which are still to be and in which they have built an the San-Lucar folk received to be found intact; for scarcely had the places mentioned, when they attak the presence of the birds in the sheep, and the poor creatures attacked them as Don Quixote did young, the nests which perhaps they had been able to use, for their I have told Manuel to go for some had built with great satisfaction. have some sent to you go for some nests in case you should wish to eggs were seen in the places esgs which I now have here. The two nests late in September.

From Lieut. W. Verner of the Rifle Brigade, an ardent ornithologist, and friend of mine, who accompanied Rudolf, Crown Prince of Austria, in his trip to the Marisma in May 1879, I received the 
"Dear Lord Lilford,-

"Yours received this afternoon. I found no nests of the Flamingo when with Rudolf; this was on May 29th, 1879. We rode many miles over the Guadalquivir marshes, and saw a flock of about 2000 birds. I found three eggs lying in the slob land about a mile from the river. The Spaniards swore that a few weeks before a man from San Lucar de Barrameda had taken about a thousand eggs. This, I am pretty sure, was a lie. From my own observations they appeared not to have begun to nest when we were there. They were in one immense flock, and flew bang out of the country after being disturbed a few times. I will look up my notes when I go to my room after mess and give any dates.

"I heard on pretty good authority, i.e. from one of the Jerez sherrygrowers, that in June 1879 the Flamingos were just beginning to nest, and that some fellow had taken a lot of eggs. You see my direct evidence is very small."

From the above it would appear that the Flamingo is a more or less permanent resident in the Marisma, and that its stay therein and departure thence are regulated by the amount of rainfall and the persecution it meets with. The question that naturally rises is, whither do the immense numbers of Flamingos which frequent the Marisma in the winter retire to breed when that district is too dry for them? This question I am unable to answer, and I should be most happy to receive any information on the subject. On the disputed question of the position of the bird on the nest, I am unable to say any thing from personal experience; but I confess that I can see no reason why the Flamingo should not sit in the same way as any other bird ${ }^{1}$; and I must add that the story of the legs stretched out behind, appears to me unnecessary, improbable, uncomfortable, and, as far as I am at present aware, quite unsupported by trustworthy evidence.

\section{June 15, 1880.}

\section{Professor W. H. Flower, LL.D., F.R.S., President, in the Chair.}

The Secretary made the following report on the additions to the Society's Menagerie during May 1880 :-

The total number of registered additions to the Society's Menagerie during the month of May was 199, of which 24 were by birth, 94 by presentation, 68 by purchase, 1 received in exchange, and 12 received on deposit. The total number of departures during the same period, by death and removals, was 106 .

The most noticeable additions during the month were :-

1. Two side-striped Jackals (Canis lateralis), from Western Africa.

$1 \mathrm{Mr}$. Saunders has also expressed his disbelief in the current "leg-story" in print and privately. 


\section{$2 \mathrm{BHL}$ Biodiversity Heritage Library}

Lyttleton, Thomas and Lilford, Thomas Littleton Powys. 1880. "6. On the Breeding of the Flamingo in Southern Spain." Proceedings of the Zoological Society of London 1880, 446-450.

https://doi.org/10.1111/j.1469-7998.1880.tb06581.x.

View This Item Online: $\underline{\text { https://www.biodiversitylibrary.org/item/90456 }}$

DOI: https://doi.org/10.1111/j.1469-7998.1880.tb06581.x

Permalink: https://www.biodiversitylibrary.org/partpdf/73366

\section{Holding Institution}

Natural History Museum Library, London

\section{Sponsored by}

Natural History Museum Library, London

\section{Copyright \& Reuse}

Copyright Status: Public domain. The BHL considers that this work is no longer under copyright protection.

This document was created from content at the Biodiversity Heritage Library, the world's largest open access digital library for biodiversity literature and archives. Visit BHL at https://www.biodiversitylibrary.org. 